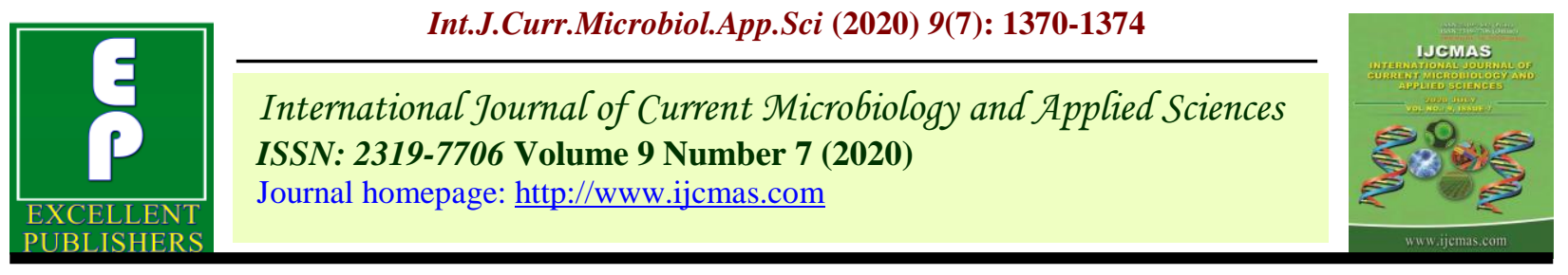

Original Research Article

https://doi.org/10.20546/ijcmas.2020.907.158

\title{
Assessment of Biochemical Profile of Pre Weaned Kids
}

\author{
Dhara D. Dhusa, S. P. Madhira, M. M. Pathan* and K. R. Joshi \\ Department of Veterinary Physiology and Biochemistry, \\ College of Veterinary Science \& A. H., AAU, Anand, India \\ *Corresponding author
}

\begin{tabular}{|l|}
\hline Ke y w o r d s \\
Biochemical, Kids, \\
Pre weaned \\
\hline Article Info \\
$\begin{array}{l}\text { Accepted: } \\
\text { 14 June } 2020 \\
\text { Available Online: } \\
10 \text { July } 2020\end{array}$ \\
\hline
\end{tabular}

\section{A B S T R A C T}

The present study was conducted on eight pre-weaned (birth to three months of age) kids. Five $\mathrm{ml}$ of whole blood samples were collected from the experimental animals on $0,7,15,30,45,60,75$ and up to 90 days age of kids. Total Protein, Cholesterol, Urea, Uric acid, Creatinine, Calcium, Phosphorus, Magnesium using diagnostic kits. Significant ( $p<0.05$ ) decrease was observed in glucose and uric acid levels from 0-90th days in kids. Cholesterol levels were significant between days $(\mathrm{p}<0.05)$ whereas, BUN, Total protein and Creatinine did not show any significant difference between days. The calcium levels decreased significantly $(\mathrm{p}<0.05)$ from 0 90th days in kids only, while inorganic phosphorus was significant between days and levels of magnesium were non-significant.

\section{Introduction}

Sheep and Goat are an important livestock species of India. They contribute greatly to the agrarian economy, especially in the arid/semiarid and mountainous regions where crop and /or dairy farming are not economical. Goats are multipurpose animals producing meat, milk, skin and hair, They are mainly concentrated in ecologically fragile, arid and semiarid areas. In India, it is generally known as "poorman's cow" and as "wet nurse". Sheep provides the much needed wool, fibers, manure and to small extent milk also. Sheep is traditionally a poor man's companion. Sheep and goat manure is an important source of soil fertility (Srivastava and Sharma, 1998).

The uterine environment ends, and the subsequent 24 hours represents a critical transition phase between the foetal functions and those of the newborn. The neonatal period is one of the most demanding adaptation periods during the life of any animal, including kids. The adaptation period to the extrauterine life begins immediately after parturition. The survival of the newborn depends on rapid adaptations to new environmental conditions which requires establishment of cardiovascular, respiratory, metabolic and thermoregulatory homeostasis 
mechanisms that are essential for survival and growth. Post-partum period represents a transition phase from intrauterine to the extrauterine environment. Nearly half of all weaned lambs die on the day of birth, while the rate of lamb losses is greatly reduced beyond the first week of life (Piccione et al., 2009). From week 34 of intrauterine life till the first post-partum hours, all blood components and the coagulation factors are subjected to continuous changes and even after this period (Piccione et al., 2008).

Good management techniques and early intervention, diagnosis and treatment could prevent a substantial proportion of neonatal diseases or death. Specific serum biochemical reference ranges could help to promote the ability of clinicians to interpret clinical pathology data more accurately and diagnosis of neonatal diseases (Piccione et al., 2008). There is a great variation in the biochemical parameters as observed between breads of goats and in this regard it may be difficult to formulate a universal metabolic profile test for lambs and kids. These differences have further underlined the need to establish appropriate physiological baseline values for lambs and kids, which could help in realistic evaluation of the management practice, nutrition and diagnosis of health condition (Tambuwal et al., 2002). Keeping in view the above points, the present study was undertaken in kids and lambs.

\section{Materials and Methods}

The research was approved by the Institutional Animal Ethics Committee (IAEC, No.: 256/VPY/2016). The present study was conducted in the Department of Veterinary Physiology and Biochemistry, College of Veterinary Science and A. H., Anand Agricultural University, Anand on eight pre-weaned (birth to three months of age)kids maintained at Instructional Livestock Farm Complex (ILFC) of Department of
Livestock Production Management at College of Veterinary Science and A.H., Anand. The experimental animals were reared in semiopen housing system which is made up of a concrete floor under asbestos roofed housing system constructed east-west direction and well covered with trees. These experimental animals were separated from other animals in pakka shed house. The experimental animals were maintained on ICAR feeding standards, 1998. Five $\mathrm{ml}$ of whole blood samples were collected from the experimental animals on 0 , $7,15,30,45,60,75$ and up to 90 days age of kids. Samples were collected aseptically from the jugular vein in heparinized vacutainer. Plasma was separated by centrifugation at $3000 \mathrm{rpm}$ for 15 minutes and stored at $-20{ }^{\circ} \mathrm{C}$ in deep freeze until analyzed for Glucose, Total Protein, Cholesterol, Urea, Uric acid, Creatinine, Calcium, Phosphorus, Magnesium using diagnostic kits manufactured by Crest Biosystems, Coral Clinical systems, Goa. The data was analyzed using a completely randomized design (CRD) and significance was tested by Duncan's New Multiple Range Test (DNMRT).

\section{Results and Discussion}

Biochemical parameters are the parameters which help in diagnosis of many conditions. Little information is available on the stress induced changes in blood biochemical profile indicating changes in metabolic pattern. In the present study, different biochemical profiles viz. glucose, blood urea nitrogen (BUN), total protein, uric acid, creatinine, cholesterol, calcium, inorganic phosphorous and magnesium were measured. The detailed result of biochemical metabolites generated after plasma analysis are presented in Table 1.

In the present study, the mean ( \pm SEM) glucose $(\mathrm{mg} / \mathrm{dl})$ concentration of kids were ranged from $72.88 \pm 4.67$ to $122.42 \pm 21.19$ with the mean value of $93.28 \pm 4.07$ from birth to three months of age which was significant. 
The highest and lowest glucose concentration was observed on $15^{\text {th }} \& 75^{\text {th }}$ day respectively. The level of glucose attained the adult values on $90^{\text {th }}$ day. The mean $( \pm$ SEM) BUN $(\mathrm{mg} / \mathrm{dl})$ of kids were ranged from $9.54 \pm 0.67$ to 12.73 \pm 1.76 with the mean value of $11.06 \pm 0.42$ from birth to three months of age which was non-significant. Here, the lowest BUN was found on 30th day. Whereas, highest BUN recorded on 90th day. Total protein $(\mathrm{g} / \mathrm{dl})$ of kids were ranged from $6.06 \pm 0.22$ to $6.64 \pm$ 0.43 and the mean was $6.38 \pm 0.12$ from birth to three months of age which was nonsignificant. Lowest Total protein was observed on 15th day, whereas, highest Total protein recorded on 45 th day. The range for creatinine $(\mathrm{mg} / \mathrm{dl})$ was $0.53 \pm 0.06$ to $0.62 \pm$ 0.10 and the mean was0.58 \pm 0.02 which was non-significant. Highest creatinine was recorded on the day of birth whereas, lowest creatinine was found on 90th day. $0.72 \pm 0.16$ to $1.99 \pm 0.83$ was the range found for uric acid with the mean of $1.21 \pm 0.12$ which was also non-significant. Highest Uric acid values were recorded on the day of birth whereas, lowest Uric acid was found on 60th day. However, a significant decrease was found in uric acid levels from 0 day to 90 th day. The mean cholesterol $(\mathrm{mg} / \mathrm{dl})$ of kids were ranged from $79.65 \pm 9.98$ to $186.51 \pm 14.81$ with the mean of $124.05 \pm 6.91$ which was significant. The highest and lowest cholesterol concentration was found on 30th and 90th day respectively as compared to 0 day of life. There were non-significant differences recorded for other days. The mean calcium $(\mathrm{mg} / \mathrm{dl})$ was ranged from $5.20 \pm 0.32$ to 10.15 \pm 3.28 with the mean of $6.61 \pm 0.49$ from birth to three months of age which was nonsignificant. The highest calcium concentration on 0 day which was decreased nonsignificantly on 7 th day. A lowest calcium concentration was found on 15th day which differed significantly $(\mathrm{p}<0.05)$ as compared to 0 day. Thereafter, non-significant differences were recorded till 90th day. The mean Inorganic phosphorus (mg/dl) was ranged from $5.52 \pm 0.54$ to $8.75 \pm 0.94$ with the mean value of $6.84 \pm 0.25$ from birth to three months of age which was significant. The lowest and highest concentration of Inorganic Phosphorus was observed on 30th and 75th day respectively. Inorganic Phosphorus did not differ significantly from 0 day till 45thday. A significantly $(\mathrm{p}<0.05)$ higher concentration of Inorganic Phosphorus was found on 60th and 75th day as compared to 0 day. Magnesium ( $\mathrm{mg} / \mathrm{dl})$ of was ranged from $2.39 \pm 0.29$ to $3.33 \pm 0.43$ with the mean value of $2.95 \pm 0.12$ from birth to three months of age which was non-significant. We observed the highest and lowest Magnesium concentration 45th day and 30thday.

Mbassa and Poulsen (1991) also observed higher glucose level at birth and then observed gradual decrease with adult age in kids of Dwarf and Danish Landrace breeds. He concluded that the higher glucose levels in initial days than in adult goats is probably due to the large energy requirements as a result of high metabolic rates. As per him urea and total protein concentration decreases within the first week of life, but later, levels increased with age. Total proteins contribute profoundly to neonate immunity and growth, not only because of the immunoglobulin content, but also because of other nutritional and physiological effects on the neonates (Chinter et al., 2013). The creatinine concentrations increased gradually and slightly with age in kids. Ashour et al., (2015) also observed lower cholesterol levels at birth in Ossimi lambs and Damascus kids which is similar to the findings observed in the present study. However, Mbassa and Poulsen, (1991) observed cholesterol level was high at the birth and then decreased with age in kids of Dwarf and Danish breed. Celi et al., (2008) also observed that plasma calcium levels decreased with age as observed in the present study. 
Table.1 Mean ( \pm SEM) values of metabolic profiles in kids $(n=8)$ from birth to 90 days

\begin{tabular}{|c|c|c|c|c|c|c|c|c|c|}
\hline Days & $\begin{array}{l}\text { Glucose } \\
\text { (mg/dl) }\end{array}$ & $\begin{array}{c}\text { BUN } \\
(\mathrm{mg} / \mathrm{dl})\end{array}$ & $\begin{array}{l}\text { Total } \\
\text { Protein } \\
\text { (g/dl) }\end{array}$ & $\begin{array}{c}\text { Creatinine } \\
(\mathrm{mg} / \mathrm{dl})\end{array}$ & $\begin{array}{l}\text { Uric acid } \\
(\mathrm{mg} / \mathrm{dl})\end{array}$ & $\begin{array}{l}\text { Cholesterol } \\
(\mathrm{mg} / \mathrm{dl})\end{array}$ & $\begin{array}{l}\text { Calcium } \\
\text { (mg/dl) }\end{array}$ & $\begin{array}{c}\text { Inorganic } \\
\text { Phosphorus } \\
\text { (mg/dl) }\end{array}$ & $\begin{array}{c}\text { Magnesium } \\
\text { (mg/dl) }\end{array}$ \\
\hline $\mathbf{0}$ & $100.28^{\mathrm{abc}} \pm 12.91$ & $11.57 \pm 0.95$ & $6.50 \pm 0.51$ & $0.62 \pm 0.10$ & $1.99^{b} \pm 0.83$ & $85.22^{\mathrm{ab}} \pm 5.74$ & $10.15^{b} \pm 3.28$ & $6.05^{\mathrm{a}} \pm 0.69$ & $2.44 \pm 0.32$ \\
\hline 7 & $108.35^{b c} \pm 10.56$ & $12.48 \pm 0.87$ & $6.58 \pm 0.58$ & $0.55 \pm 0.09$ & $1.68^{\mathrm{ab}} \pm 0.27$ & $96.59^{\mathrm{ab}} \pm 12.85$ & $6.87^{\mathrm{ab}} \pm 1.47$ & $6.99^{\mathrm{abc}} \pm 0.78$ & $3.13 \pm 0.40$ \\
\hline 15 & $122.42^{c} \pm 21.19$ & $11.13 \pm 1.61$ & $6.09 \pm 0.15$ & $0.59 \pm 0.09$ & $1.07^{\mathrm{ab}} \pm 0.17$ & $133.18^{b c} \pm 7.51$ & $5.20^{\mathrm{a}} \pm 0.32$ & $6.64^{\mathrm{ab}} \pm 0.44$ & $2.92 \pm 0.36$ \\
\hline 30 & $100.23^{\mathrm{abc}} \pm 9.12$ & $9.54 \pm 0.67$ & $6.06 \pm 0.22$ & $0.60 \pm 0.13$ & $1.10^{\mathrm{ab}} \pm 0.17$ & $186.51^{d} \pm 14.81$ & $6.17^{\mathrm{ab}} \pm 0.57$ & $5.52^{\mathrm{a}} \pm 0.54$ & $2.39 \pm 0.29$ \\
\hline 45 & $83.39^{\mathrm{ab}} \pm 5.76$ & $10.23 \pm 1.10$ & $6.64 \pm 0.43$ & $0.61 \pm 0.06$ & $1.21^{\mathrm{ab}} \pm 0.14$ & $124.65^{\mathrm{abc}} \pm 26.65$ & $5.77^{\mathrm{ab}} \pm 0.70$ & $6.00^{\mathrm{a}} \pm 0.56$ & $3.21 \pm 0.41$ \\
\hline 60 & $83.35^{\mathrm{ab}} \pm 4.17$ & $9.97 \pm 0.89$ & $6.18 \pm 0.07$ & $0.59 \pm 0.08$ & $0.72^{\mathrm{a}} \pm 0.16$ & $170.70^{\text {cd }} \pm 19.14$ & $6.30^{\mathrm{ab}} \pm 0.52$ & $8.16^{b c} \pm 0.54$ & $2.98 \pm 0.28$ \\
\hline 75 & $72.88^{a} \pm 4.67$ & $10.87 \pm 1.24$ & $6.52 \pm 0.12$ & $0.56 \pm 0.07$ & $1.03^{\mathrm{ab}} \pm 0.15$ & $115.90^{\mathrm{ab}} \pm 17.27$ & $6.27^{\mathrm{ab}} \pm 0.58$ & $8.75^{c} \pm 0.94$ & $3.33 \pm 0.43$ \\
\hline 90 & $75.30^{\mathrm{ab}} \pm 2.70$ & $12.73 \pm 1.76$ & $6.45 \pm 0.20$ & $0.53 \pm 0.06$ & $0.87^{\mathrm{a}} \pm 0.13$ & $79.65^{\mathrm{a}} \pm 9.98$ & $6.17^{\mathrm{ab}} \pm 0.78$ & $6.59^{\mathrm{ab}} \pm 0.49$ & $3.24 \pm 0.26$ \\
\hline GM & $93.28 \pm 4.07$ & $11.06 \pm 0.42$ & $6.38 \pm 0.12$ & $0.58 \pm 0.02$ & $1.21 \pm 0.12$ & $124.05 \pm 6.91$ & $6.61 \pm 0.49$ & $6.84 \pm 0.25$ & $2.95 \pm 0.12$ \\
\hline CV\% & 31.98 & 30.37 & 15.01 & 42.30 & 78.52 & 35.58 & 58.63 & 26.48 & 33.53 \\
\hline $\mathrm{CD}_{0.05}$ & 29.98 & - & - & - & - & 44.36 & & 1.82 & \\
\hline
\end{tabular}

Values having different superscripts differed significantly $(\mathrm{P}<0.05)$ within column 
However, Jagos et al., (1980) reported that the mean concentration of plasma Calcium in calves varied in first week of age which dropped to the lowest value at the age of 14 days. Calcium requirements for pregnancy and lactation are higher than those for maintenance, which increases the quantity of Calcium required at tissue level and thereby increases Calcium absorption from the gastrointestinal tract of sheep and goats, which subsequently is reflected is in the newborn. However, Jagos et al., (1980) reported that the level of inorganic phosphorus gradually decreased from high concentration during early days of life, while Siddique (2011) stated that phosphorus level varied significantly $(p<0.05)$ in calves with advancement of age.

In conclusions, significant $(\mathrm{p}<0.05)$ decrease was observed in glucose and uric acid levels from 0-90th days in kids. Cholesterol levels were significant between days $(\mathrm{p}<0.05)$ whereas, BUN, Total protein and Creatinine did not show any significant difference between days. The calcium levels decreased significantly $(\mathrm{p}<0.05)$ from $0-90$ th days in kids only, while inorganic phosphorus was significant between days and levels of magnesium were non-significant.

\section{References}

Celi, P., Di Trana, A. A., Claps, S., and Di Gregorio, P. (2008). Effects of perinatal nutrition on metabolic and hormonal profiles of goat kids (Capra hircus) during their first day of life. Asian-Aust. J. Anim. Sci, 21, 1585-1591.

Chniter, M., Hammadi, M., Khorchani, T., Sassi,
M. B., Hamouda, M. B., and Nowak, R. (2013). Aspects of neonatal physiology have an influence on lambs' early growth and survival in prolific D'man sheep. Small Ruminant Research, 111 (1-3), 162-170.

Jagos, P., Dvorak, V., and Bouda, J. (1980). Levels of Minerals in the Blood Plasma of Cows and Their Calves Fed from Buckets. Acta. Vet. Brno., 50, 33-41.

Mbassa, G. K., and Poulsen, J. S. D. (1991). The comparative haematology of cross-bred and indigenous East African goats of Tanzania and breeds reared in Denmark. Veterinary Research Communications, 16 (3), 221229.

Piccione, G., Bertolucci, C., Giannetto, C. and Giudice, E. (2008). Clotting profiles in newborn Maltese kids during the first week of life, J. Vet. Diagn. Invest., 20, 114-118.

Piccione, G., Casella, S., Giannetto, C., Vazzana, I., Niutta, P. P. and Giudice, E. (2009). Influence of age on serum proteins in the calf. Acta Veterinaria Beograd, 59, 413422.

Saddiqi, H. A., Nisa, M., Mukhtar, N., Shahzad, M. A., Jabbar, A., and Sarwar, M. (2011). Documentation of physiological parameters and blood profile in newly born Kajli lambs. Asian-Australasian Journal of Animal Sciences, 24 (7), 912-918.

Srivastava, S. N. and Sharma, K. (1998). Feed Intake, Nutrient Utilization and Growth Rate of Jamunapari Goats Fed Sundried Leucaena Leucocephala. Ajas, 11, 337-343.

Tambuwal, F. M., Agale, B. M. and Bangana, A. (2002). Haematological and biochemical values of apparently healthy Red Sokoto goats. Proc. 27th Annual Conference Nigerian Society of Animal Production (NSAP), 17-21 March, FUTA, Akure, Nigeria. 50-53.

\section{How to cite this article:}

Dhara D. Dhusa, S. P. Madhira, M. M. Pathan and Joshi, K. R. 2020. Assessment of Biochemical Profile of Pre Weaned Kids. Int.J.Curr.Microbiol.App.Sci. 9(07): 1370-1374. doi: https://doi.org/10.20546/ijcmas.2020.907.158 